\title{
Effect of Bagasse Ash on the Properties of Cement Stabilized Black Cotton Soil
}

\author{
Ahmad Batari", Adamu Umar Chinade, Saeed Modibbo Saeed, Ibrahim Abdulkarim Ikara, \\ Nasir Kabir, Abubakar Mamuda
}

Department of Civil Engineering, Abubakar Tafawa Balewa University, Bauchi, Nigeria

\section{Email address:}

ahmadbatari@gmail.com (A. Batari), umarchinade@yahoo.com (A. U. Chinade), abukhadijatsms@gmail.com (S. M. Saeed), ikara12@yahoo.com (I. A. Ikara), naskabirnasir@gmail.com (N. Kabir), abubakarsadeeg13@gmail.com (A. Mamuda)

${ }^{*}$ Corresponding author

\section{To cite this article:}

Ahmad Batari, Adamu Umar Chinade, Saeed Modibbo Saeed, Ibrahim Abdulkarim Ikara, Nasir Kabir, Abubakar Mamuda. Effect of Bagasse Ash on the Properties of Cement Stabilized Black Cotton Soil. International Journal of Transportation Engineering and Technology.

Vol. 3, No. 4, 2017, pp. 67-73. doi: 10.11648/j.ijtet.20170304.14

Received: September 30, 2017; Accepted: December 3, 2017; Published: December 5, 2017

\begin{abstract}
When proximate and locally available materials to be used for road pavement construction are deficient to meet the nominal requirements of the intended flexible pavement layer; then stabilization becomes necessary. Therefore, this paper presents the results of laboratory experiments undertaken to assess the effect of sugarcane Bagasse Ash (BA) as an admixture to cement stabilized Black Cotton Soil (BCS). The Bagasse was obtained from a dump-site at Kasuwan Shanu market Bauchi and was incinerated at a controlled temperature range between $600^{\circ} \mathrm{C}$ and $700^{\circ} \mathrm{C}$ to get the $\mathrm{BA}$, while the $\mathrm{BCS}$ was obtained along Kanawa-Jauro-Gotel road, in Yemaltu-Deba, Gombe, Nigeria. The specimens were prepared by admixing the four blends of cement stabilized BCS (using $0,4,6$, and $8 \%$ cement) with stepped percentage of BA $(0,1,2,34,5$, and $6 \%$ ) by dry weight of the BCS. The experiments carried out on both the natural and treated BCS include; Atterberg's limits, Sieve/hydrometer analysis, Free swell, Compaction, soaked California Bearing Ratio (CBR), and Unconfined Compressive Strength (UCS) at 7, 14, and 28 days curing periods. The BCS was classified as A - 7-6 (68), and $\mathrm{CH}$ (high plasticity clay) using the American Association of State Highway and Transportation Officials (AASHTO) and Unified Soil Classification System (USCS) respectively. In addition, the soil was also categorized as High swell potential BCS under Nigerian Building and Road Research Institute (NBRRI) classification. It was found that; addition of BA to cement stabilized BCS affected their compaction characteristics, and improved both the soaked CBR, and the UCS. On the other hand, the addition of BA alone does not improve the strength properties of the natural BCS. The optimum blend was achieved with $5 \% \mathrm{BA}$ as admixture to BCS stabilized with $8 \%$ cement, this blend gave a 7-days soaked CBR of $73 \%$ and a UCS value of $851 \mathrm{kN} / \mathrm{m}^{2}$ after curing for 7 days therefore, satisfied the sub-base requirements of the Nigerian Federal Ministry of Works. This study finally recommends the use of 5\% BA with $8 \%$ cement for BCS stabilization for use as sub-base in flexible pavement construction.
\end{abstract}

Keywords: Bagasse, Black Cotton Soil, Stabilization, California Bearing Ratio, Unconfined Compressive Strength

\section{Introduction}

Expansive soils are soils that are highly sensitive to moisture variation; they show large volume change when exposed to moisture content fluctuations [1] [2] Because the cotton plant grows well on this soil type it is often referred to as Black Cotton Soils (BCS), they have colours ranging from light-grey to dark-grey and black [1] [3].

In Nigeria BCS are often found in North Eastern part of the country, and it is believed that these soils derived their origin in Nigeria [4]. BCS have highly reactive clay minerals consisting of montmorillonite, the severe damage to structures on BCS depends on the amount of monovalent cations absorbed into this clay mineral [2]. Deposits of BCS show a general pattern of cracks during the dry season [3].

BCS are not the same in their properties and behaviors. Therefore, the Nigerian Building and Road Research Institute (NBRRI) have classified BCS into three categories (Table 1) based on two simply determinable parameters due to their 
efficacy for the purpose. The parameters are; Plasticity Index (PI) and Free Swell (FS).

Table 1. Nigerian Classification of Black Cotton Soil.

\begin{tabular}{llll}
\hline Swell Potential & PI (\%) & Free Swell (\%) & $\mathbf{1}$ micron Finer (\%) \\
\hline Low & $<20$ & $<50$ & $<20$ \\
Moderate & $15-30$ & $50-80$ & $20-30$ \\
High & $>30$ & $>80$ & $>30$ \\
\hline
\end{tabular}

BCS or expansive soils are sometimes classified on the basis of Free Swell Ratio (FSR) as; low swell, moderate swell, high swell, and very high swell [5].

These soils are peculiar with good agricultural yield or fertility, but very poor as far as construction of civil engineering facilities for both vertical and horizontal structures like buildings, bridges, rails, roads, etc, is concerned [2] [6] [7].

For effective load transfer to the subsoil beneath a structure such as building or road, its foundation is an integral part. Because, the soil quality to a greater extent dictates the type of structure and its design [8].

Soil improvement becomes necessary, when problematic soils like BCS are encountered, to ensure the integrity of the intended structure is protected against possible failures. The problematic soil is either removed and replaced with a better material which is often not economical, or resorting to changing the nature of the BCS through; compaction control, pre-wetting, moisture barrier installation, or chemically stabilizing the problem soil using some additives [8] [9] [10]. Chemical stabilization is commonly regarded as the most effective method of BCS or expansive soil improvement, when the right additive is used; it changes the nature of the soil, strengthen it, and removes its sensitivity both to water and subsequent stress [6]. In line with this, numerous waste materials have been used in stabilizing problematic soils. Various researchers reported that improvements in both physical and mechanical properties of BCS were achieved when additives such as lime, fly ash, glass fibers, cement, rice husk ash, wood ash, coconut shell ash, sugarcane straw/stalk ash (Bagasse Ash), etc, have been used alone or in combination to stabilize BCS [2] [3] [8] [10]-[14]. Furthermore, utilizing waste materials to improve desired properties of materials for road pavement will provide two folds benefits in achieving sustainability [15], i.e., managing the waste and material properties improvement at lower cost.

Sugarcane is grown in over 110 countries with a total annual production exceeding 150 million tons [16]. Bagasse is the fibrous residue obtained from sugar cane plant after the juice has been extracted, this residue is normally deposited indiscriminately, thus polluting our environment [3] [17], when incinerated, the ash obtained is known as Bagasse Ash (BA). Quantitatively, about $40-45 \%$ fibrous residue is left After the extraction of the juice from sugarcane, furthermore, most sugar industries reuse the Bagasse residue as boiler fuel for heat generation leaving behind $8-10 \%$ Bagasse Ash [16].

Fully calcined bagasse ash is obtainable at temperatures between $700^{\circ} \mathrm{C}$ to $800^{\circ} \mathrm{C}$ [2] [7], and should have a combined percent composition of $\mathrm{SiO}_{2}, \mathrm{Al}_{2} \mathrm{CO}_{3}$ and $\mathrm{Fe}_{2} \mathrm{O}_{3}$ of more than
$70 \%$ based on ASTM C618 requirements. Although BA obtained through open burning and incineration between $500^{\circ} \mathrm{C}-700^{\circ} \mathrm{C}$ in a locally made kiln [3] [6] [18] were also found to be pozzolanic to some extent due to their high silica content and were able to enhance properties of BCS.

Thus, $\mathrm{BA}$ is pozzolanic, and the common oxide compositions are; $\mathrm{SiO}_{2}, \mathrm{Al}_{2} \mathrm{O}_{3}, \mathrm{Fe}_{2} \mathrm{O}_{3}, \mathrm{CaO}, \mathrm{MgO}, \mathrm{Na}_{2} \mathrm{O}$, and $\mathrm{K}_{2} \mathrm{O}$ [3] [17] [18]. Though, pozzolanas are generally siliceous in nature, but they have no cementitious value themselves [18], this is why pozzolanas are regarded and used as supplementary cementitious materials commonly admixed to; lime or cement. In addition, Pozzolanas normally need the presence of water for the silica to combine with calcium hydroxide to form stable calcium silicate, which has cementitious properties [17]. Consequently, when BA in finely grounded form, is admixed to cement in the presence of sufficient moisture, it will chemically react with calcium oxides in the cement at ordinary temperatures to form compounds possessing cementitious property. There are various ways BA can be utilized; as adsorbent in ceramics, in biomass ash filters, in stabilized earth blocks, in burned clay bricks, in black cotton soil bricks, and in soil stabilization. Therefore, this study investigates the effect of Bagasse Ash (BA) as an admixture in cement stabilized Black Cotton Soil (BCS) to determine the optimum blends that will meet the requirements for a given layer of flexible pavement.

\section{Materials and Methods}

\subsection{Materials}

\subsubsection{Expansive Soil (BCS)}

The soil sample used in this study was obtained by a method of disturbed sampling at a depth of at least $0.5 \mathrm{~m}$ below ground level along Kanawa-Jagali-Jauro Gotel road in Yamaltu Deba Local Government of Gombe State, Nigeria.

\subsubsection{Cement}

Grade $42.5 \mathrm{~N}$, Dangote brand of ordinary Portland cement which is commonly available in the open market was utilized in this study.

\subsubsection{Bagasse Ash (BA)}

The Bagasse was obtained from an open dump site at Kasuwan-Shanu market Bauchi, Bauchi state. Thereafter, the BA was obtained after incinerating the Bagasse at a regulated temperature within $600^{\circ} \mathrm{C}-700^{\circ} \mathrm{C}$ and was then passed through B. S. sieve No. $200(0.075 \mathrm{~mm})$ to meet ASTM (618-78) requirements.

\subsection{Methods}

\subsubsection{Determination of Index Properties}

The properties of the natural and stabilized BCS were assessed in accordance with BS 1377 [19] and BS 1924 [20] respectively. Cement at $0,4,6$, and $8 \%$ were admixed with stepped percentages of BA at; $0,1,2,3,4,5$, and $6 \%$ by dry weight of the natural soil for the stabilization. While the Free 
Swell (FS) was evaluated as the percentage increase in volume of the BCS upon saturation to the initial volume.

\subsubsection{Compaction}

Appropriate quantities of BCS were separately blended with cement and were further admixed with various amount of BA to obtain the Cement/BA stabilized BCS blends (Sec. 2.2.1).

According to Moses and Osinubi [3] Standard Proctor (SP) is the recommended compactive effort over the higher compaction energies (West African Standard and Modified Proctor) for Cement/BA stabilized BCS. Therefore only SP compactive effort was utilized in this study. The SP compaction was achieved in 3-layers, each receiving 27-blows from a $2.5 \mathrm{~kg}$ rammer falling from a height of $300 \mathrm{~mm}$ in a proctor mould $\left(1000 \mathrm{~cm}^{3}\right)$.

\subsubsection{California Bearing Ratio (CBR) Test}

The soaked CBR was conducted in accordance with BS 1377. About $6 \mathrm{~kg}$ of each Cement/BA stabilized BCS blend was compacted in 3-layers, each receiving 62 blows from $2.5 \mathrm{~kg}$ rammer dropping a height of $300 \mathrm{~mm}$ above the specimen surface in a CBR mould $\left(2360 \mathrm{~cm}^{3}\right)$. These specimens were soaked for a period of 7-days before testing with CBR machine.

\subsubsection{Unconfined Compressive Strength (UCS) Test}

The various Cement/BA BCS blends for UCS tests were mixed and left to mature for 2 hours before compacting at standard proctor energy levels (Sec. 2.2.2). Prior to testing; the extruded specimens for the UCS test were cellophane cured for periods of 7, 14 and 28 days. The test was conducted in accordance with BS 1377.

\section{Results and Discussions}

\subsection{Index Properties}

The test results on the natural BCS are shown in Table 2. The soil was classified as A $-7-6(68)$ and $\mathrm{CH}$ (Sandy-Fat Clay), and as High swell potential under the AASHTO classification, USCS, and NBRRI [22] classification systems respectively. In addition it is alkaline with dark-grey coloration. The soil has respective values $94 \%$ and $74 \%$ for LL and PI; this signifies that the soil does not meet the nominal requirements of; base, sub-base, or capping layer [4]. Also having group index of more than 20 the natural BCS is not a good sub-grade material [5].

Table 2. Properties of Natural BCS.

\begin{tabular}{ll}
\hline Property & Results \\
\hline Percent Passing No. 200 Sieve & 84.5 \\
Initial water content (\%) & 16.0 \\
Color & Dark-grey \\
pH (Universal Indicator) & 7.6 \\
Liquid Limit (\%) & 94.0 \\
Plastic Limit (\%) & 20.0 \\
Plasticity Index (\%) & 74.0 \\
Group Index (GI) & 68 \\
Free Swell (\%) & 88.2 \\
Classification: AASHTO & $\mathrm{A}-7-6$ (68) \\
\multicolumn{1}{c}{ : USCS } & $\mathrm{CH}(\mathrm{High}$ Plasticity Clay) \\
& High Swell Potential BCS \\
Maximum Dry Density (Mg/m $\left.{ }^{3}\right)$ & 1.43 \\
Optimum Moisture Content $(\%)$ & 30.9 \\
CBR (\%) 7-days Soaked & 2 \\
Unconfined Compressive Strength $\left(\mathrm{kN} / \mathrm{m}^{2}\right)$ & 332 \\
@ 7-days &
\end{tabular}

\subsection{Compaction Characteristics}

\subsubsection{Maximum Dry Density (MDD)}

Variation of MDD for the BCS-Cement-BA blends is presented in Figure 1. For the entire blend there was an initial gradual increase in MDD with increasing BA content.

The MDD decreases after peak at $4 \% \mathrm{BA}$ (for $4 \%$, and $8 \%$ cement) and at $5 \%$ BA (for $0 \%$, and $6 \%$ cement). Furthermore, there was general increase in MDD with increasing the cement up to $8 \%$.

It was viewed that the MDD increased up to peak was due to voids within the soil being occupied by cement and ash particles [3]. While the MDD decrease after peak; this decrease was attributed to increased amount of low specific gravity BA particles replacing higher specific gravity BCS [8].

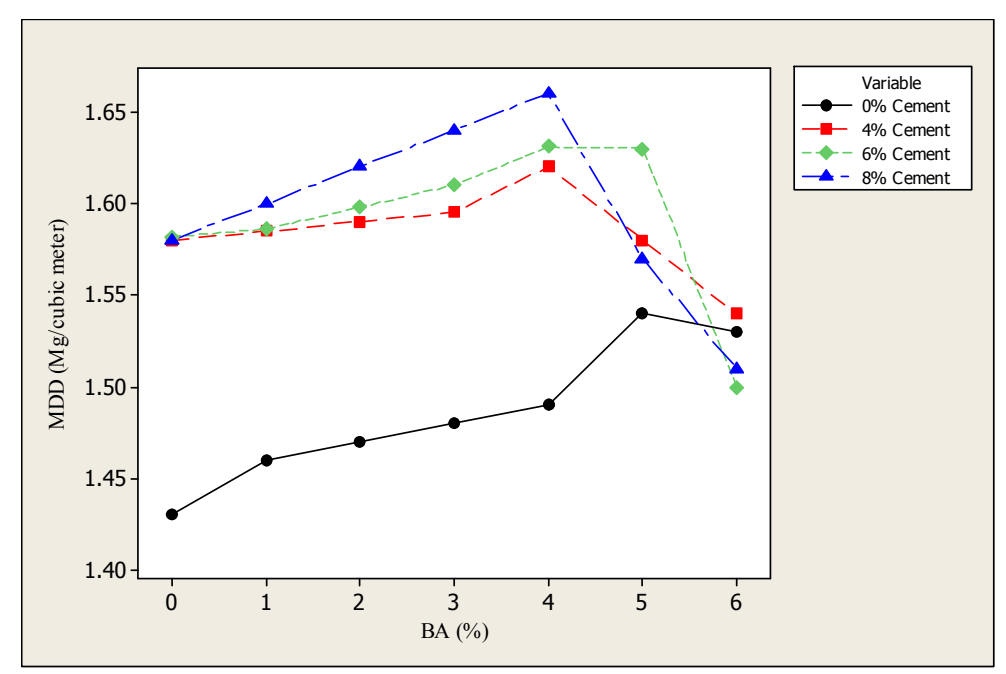

Figure 1. Variation of $M D D$ with BA for various cement content. 


\subsubsection{Optimum Moisture Content (OMC)}

The variation of Optimum Moisture Content (OMC) of the blends with Bagasse ash content for various cement contents is presented in Figure 2. The natural BCS shows a continual decrease in OMC with increasing BA contents, this was in agreement with past researches [3] [8]. But for the blends with at least $2 \%$ cement; the OMC shows an initial increase then decreases. The initial increase might be due to increased water demand by the cations (supplied by the cement and BA) and the BCS clay mineral particles to undergo hydration. While the decrease in OMC on the other hand could have been due to cations exchange [3] causing flocculation of the clay particles.

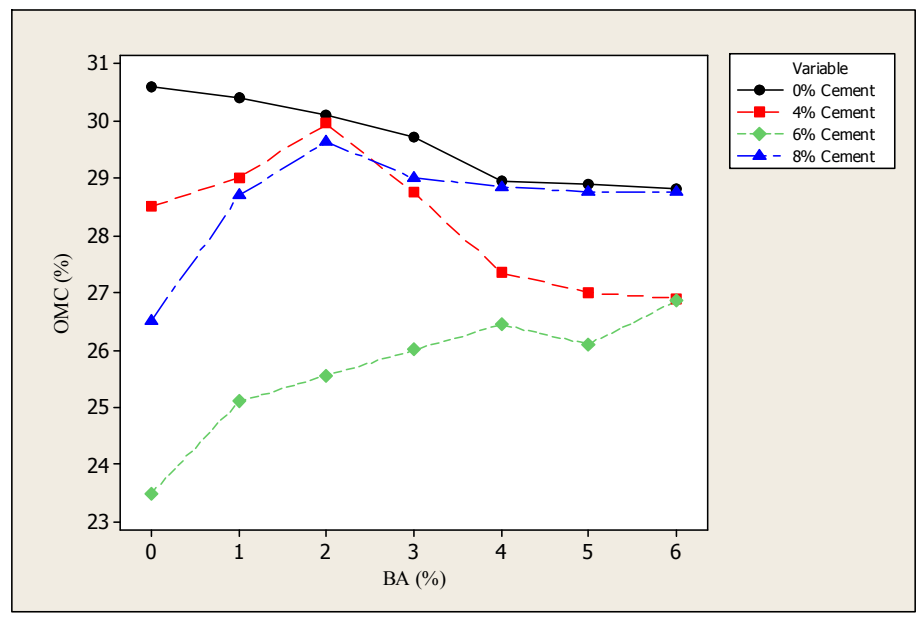

Figure 2. Variation of $O M C$ with BA for various cement content.

\subsection{California Bearing Ration (CBR)}

The CBR value of any soil, gives an indication of its bearing capability and strength. CBR needs to be appropriately evaluated, for the fact that if overestimated, there will be a high tendency of un-satisfactory highway performance and premature failure. On the other hand, if the CBR is underestimated, the pavement will be thicker, stronger but un-economical [4]. Therefore, CBR is an important parameter to consider for assessing road pavement materials' suitability or otherwise for: sub-grade, capping, sub-base or base. In addition, where there is tendency of wetting for a substantial period during the pavement life, soaking for a period of 4-days or more is recommended by [4]. Figure 3 presents the variation of the CBR (7-days soaked) with BA for various cement contents. For blends without cement, the addition of up to $6 \%$ BA does not improve the CBR. Thus having CBR less than 5\%, they cannot be used as sub-grade without capping layer (i.e. material with at least $15 \%$ soaked CBR) as recommended by [4].

However, general improvement in the soaked CBR was observed with progressive addition of cement from $4 \%$ through $6 \%$. Addition of BA to cement stabilized BCS increases the CBR values, then, decreases with further addition. Peak CBR values of $49 \%, 53 \%$ and $73 \%$ were achieved for the blends with 4\% Cement 3\% BA, 6\% Cement 3\% BA, and $8 \%$ Cement 5\% BA respectively. Unfortunately, none of these blends met the nominal $80 \%$ soaked CBR requirement for base course, but regardless of the BA content; the entire blends with at least $4 \%$ cement have achieved the nominal 30\% CBR required for sub-base except; BCS blend with 4\% cement plus $6 \%$ BA. Meanwhile, the stabilization of the BCS with $8 \%$ cement admixed with 5\% BA could be the optimum.

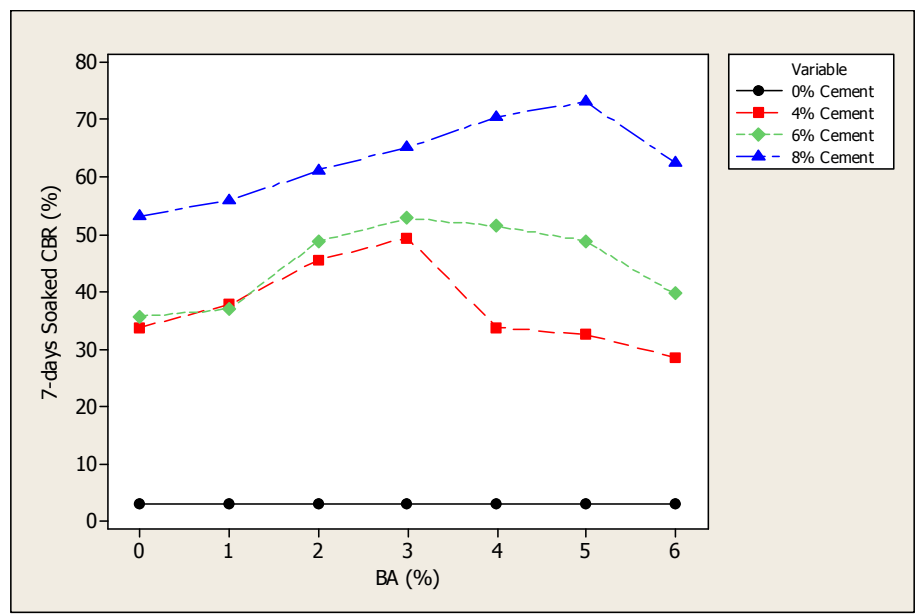

Figure 3. Variation of 7-days Soaked CBR with BA for various cement content. 


\subsection{Unconfined Compressive Strength (UCS)}

The Unconfined Compressive Strength (UCS) test is an important test [23] recommended by the Nigerian Federal Ministry of Works [4], for evaluating the strength of cemented materials for use as either base, or sub-base. But is not a requirement for capping or sub-grade layer. The test is also vital for determining the additive quantity to achieve optimum soil stabilization. The minimum 7-days UCS values required by this specification [4], ranges between $750-1500$ $\mathrm{kN} / \mathrm{m}^{2}$, and $1500-3000 \mathrm{kN} / \mathrm{m}^{2}$ for sub-base and base courses, respectively. The results of the UCS tests conducted on the cement stabilized BCS admixed with BA for 7, 14 and 28-days curing, are shown in Figure 4, 5, 6. Peak UCS (7-days cured) values of $393 \mathrm{kN} / \mathrm{m}^{2}$ for blend with $4 \%$ Cement-0\% BA, $660 \mathrm{kN} / \mathrm{m}^{2}$ at 4\% Cement-4\% BA, while $823 \mathrm{kN} / \mathrm{m}^{2}$ at $6 \%$ Cement- $5 \%$ BA and $851 \mathrm{kN} / \mathrm{m}^{2}$ at $8 \%$ Cement-5\% BA were recorded. The entire blends do not meet the UCS criterion for base course. However, the blends with $6 \%$ cement $-5 \%$ BA and $8 \%$ cement-5\% BA met the UCS requirement for sub-base. Therefore, the blend with $8 \%$ cement-5\% BA (UCS value of $851 \mathrm{kN} / \mathrm{m}^{2}$ ) could be the optimum blend. There was a significant strength development with curing age due to pozzolanic activity as shown in Figure 5, 6, in comparison to the 7-days UCS.

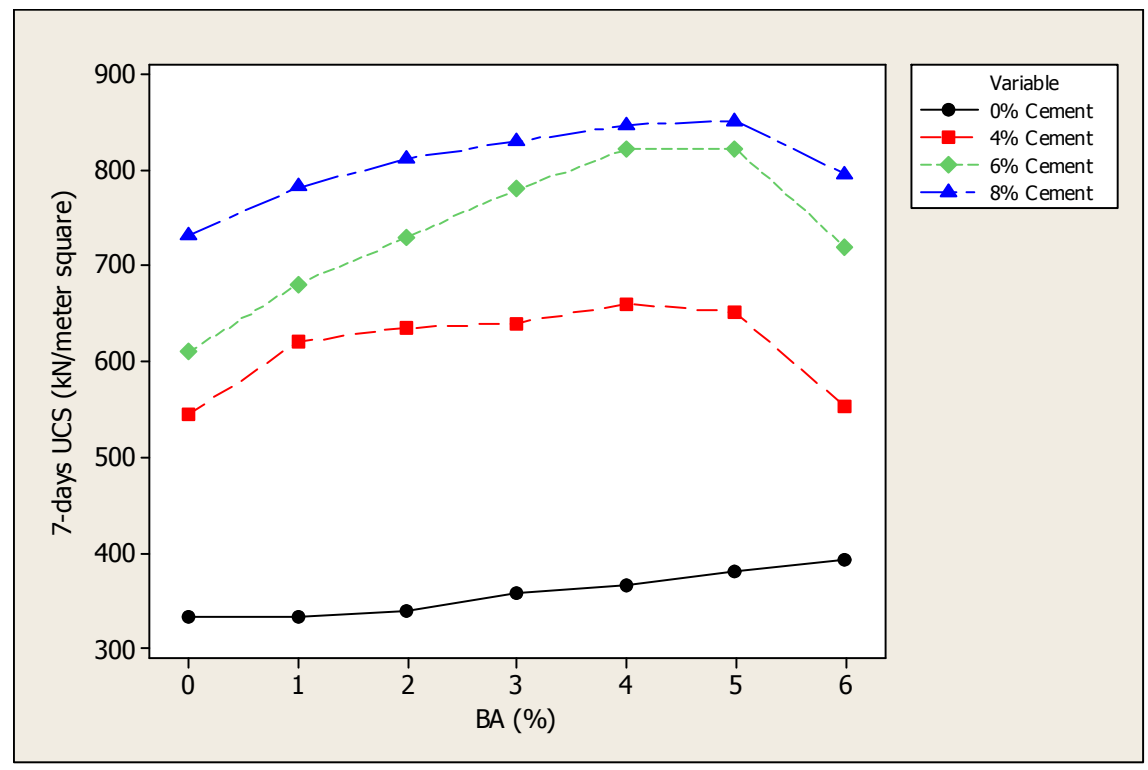

Figure 4. Variation of 7-days UCS with BA for various cement content.

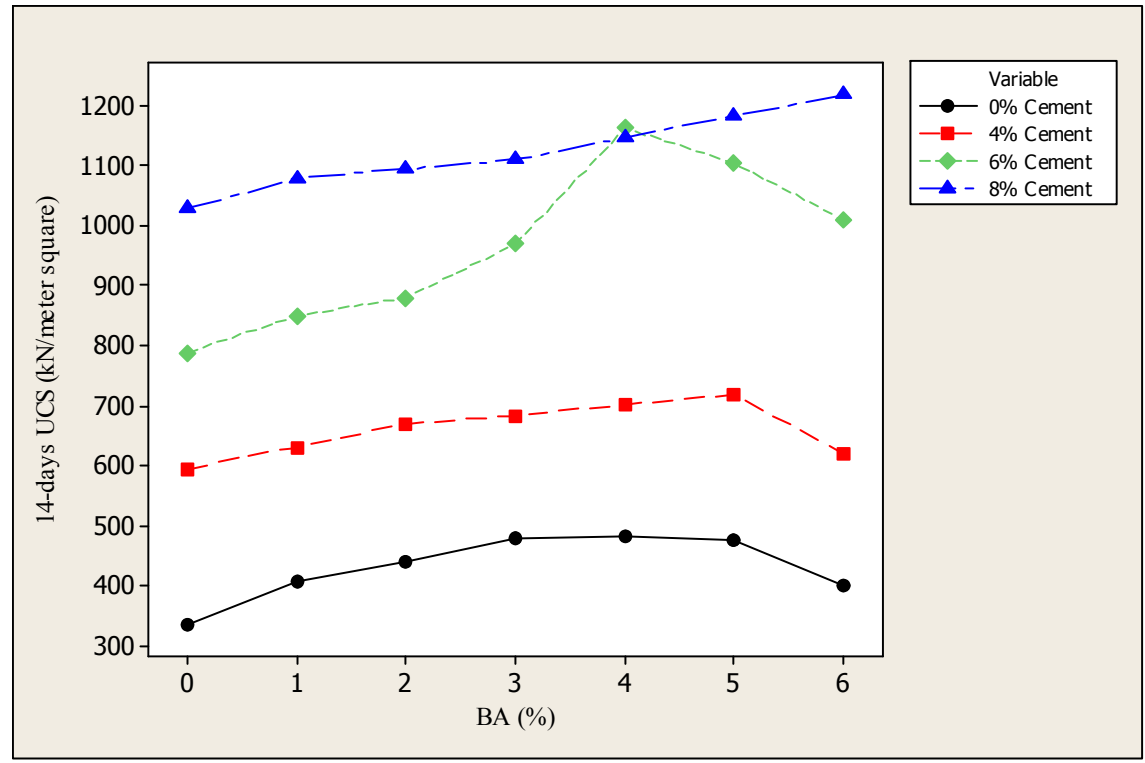

Figure 5. Variation of 14-days UCS with BA for various cement content. 


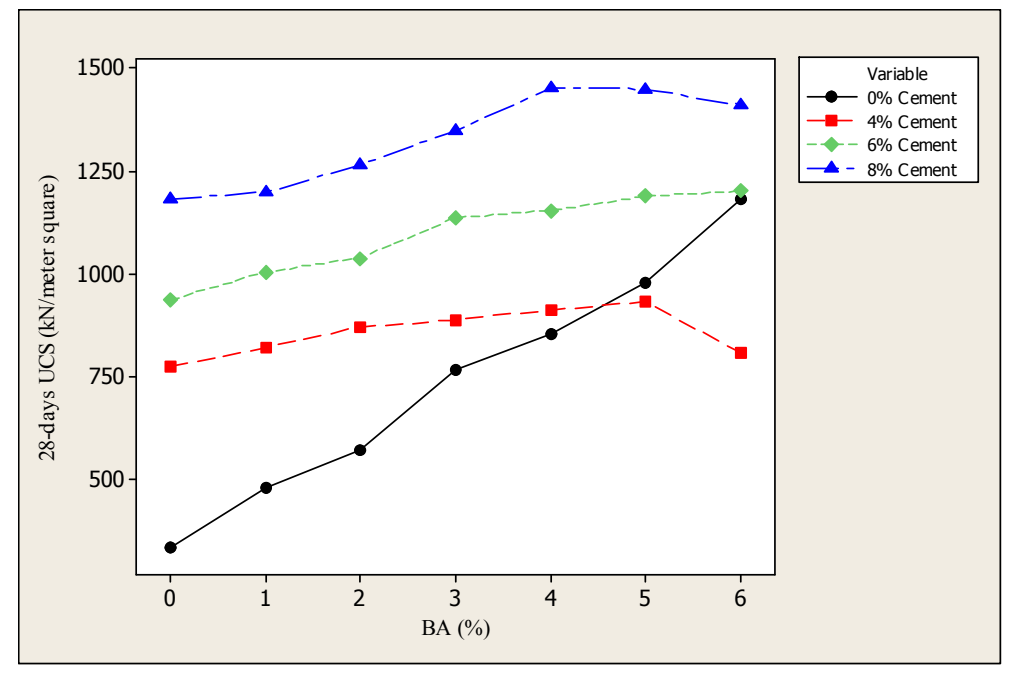

Figure 6. Variation of 28-days UCS with BA for various cement content.

\section{Conclusions}

The Black Cotton Soil (BCS) used in this study was classified as $\mathrm{A}-7-6$ (68), high plasticity clay $\mathrm{CH}$ and as High swell potential BCS, under the AASHTO, USCS, and NBBRI classification systems respectively. Therefore, the natural BCS is very poor for pavement engineering applications. The MDD's and OMC's of the soil were affected by treatment with both cement and Bagasse Ash (BA). And 73\% Soaked (7-days) CBR value was achieved with $8 \%$ Cement $-5 \%$ BA stabilization of the BCS. This value is slightly below the recommended $80 \%$ CBR for base material; however, it met the $\mathrm{CBR}$ reqirement of a sub-base material. In addition, the BCS blend with $8 \%$ Cement - 5\% BA has a 7-days UCS value of $851 \mathrm{kN} / \mathrm{m}^{2}$, thus, did not met the base course requirement of the Nigerian Federal Ministry of Works [4], but fell within the range (750 $1500 \mathrm{kN} / \mathrm{m}^{2}$ ) of the 7-days UCS recommended for sub-base. On the other hand, no improvement in strengths (Both UCS and CBR) was observed when BA alone was used to stabilize the BCS. Therefore, BA alone could not be used for stabilization of this type of black cotton soil. Finally, this study recommended the use of 5\% BA and $8 \%$ cement as the optimum blend for the stabilization of black cotton soil to be used as sub-base in flexible pavement.

\section{References}

[1] R. Jatav, "Comparison of Geotechnical Engineering Properties of Black Cotton Soil by Adding Lime and Sugarcane Straw Ash,”vol. 3, no. 4, pp. 103-105, 2016.

[2] L. C. Dang, H. Hasan, B. Fatahi, R. Jones, and H. Khabbaz, "Enhancing the Engineering Properties of Expansive Soil Using Bagasse Ash and Hydrated Lime," Int. J. GEOMATE, vol. 11, no. 25, pp. 2447-2454, 2016.

[3] G. Moses and K. J. Osinubi, "Influence of Compactive Efforts on Cement- Bagasse Ash Treatment of Expansive Black Cotton Soil," Int. J. Civil, Environ. Struct. Constr.
Archit. Eng., vol. 7, no. 7, pp. 1541-1548, 2013.

[4] FMW, "Highway Manual Part 1: Pavement and Materials Design," Federal Republic. of Nigeria., vol. III, no. March, 2013.

[5] B. M. Das, Principles of Foundation Engineering, 7th ed. Stamford, USA: Cengage Learning, 2007.

[6] B. A. Mir, K. Gupta, and J. N. Jha, "Some Studies on The Behavior of Sugarcane Bagasse Ash Admixed With Cement Stabilized Soil," Int. Conf. Soil Environ. ICSE, Bangalore, pp. 1-8, 2016.

[7] L. C. Dang, H. Hasan, B. Fatahi, and H. Khabbaz, "Influence of Strength and Mechanical Behaviour of Bagasse Ash and Hydrated Lime Stabilized Expansive Soil," GEOQuebec 2015 - Challenges from North to South, 20- 23 Sept., 2015.

[8] A. S. Kharade, V. V Suryavanshi, B. S. Gujar, and R. R. Deshmukh, "Waste Product ' Bagasse Ash ' From Sugar Industry Can Be Used As Stabilizing Material for Expansive Soils," IJRET Int. J. Res. Eng. Technol., vol. 1, no. 1, pp. 506-512, 2014.

[9] M. A. Mu'Azu, "Influence of compactive effort on Bagasse ash with cement treated lateritic soil," Leonardo Electron. J. Pract. Technol., vol. 10, no. 1, pp. 79-92, 2007.

[10] A. Pandey and U. K. Maheshwari, "Influence of Soil Fly Ash And Soil-Bagasse Ash Mixture on Hydraulic Conductivity of Soils," 2017, pp. 12-21.

[11] D. T. Sekar, "Utilization of Industrial Wastes for Production of Black Cotton Soil Bricks," Int. Res. J. Eng. Technol., vol. 2, no. 5, pp. 1089-1094, 2015.

[12] S. Rani, P. Kumar, R. K. V. Krishna, and S. Praveen, "Stabilization of Clay At Sunnam Cheruvu Area in Nadergul, Hyderabad Using Organic Waste," in Indian Geotechnical Conference IGC, 2016, no. December, pp. 15-18.

[13] K. C. Onyelowe, "Cement Stabilized Akwuete Lateritic Soil and the Use of Bagasse Ash as Admixture," Int. J. Sci. Eng. Investig., vol. 1, no. 2, pp. 16-20, 2012.

[14] A. Mathew and K. Y. Raneesh, "Effect on Strength Characteristics of Expansive Soil Using Sisal Fibre and Waste Materials,” vol. 5, no. 9, pp. 1702-1707, 2016. 
[15] A. Batari, M. Y. Aman, S. M. Saeed, T. Y. Ahmed, and A. U. Chinade, "Rutting Assessment of Crumb Rubber Modifier Modified Warm Mix Asphalt Incorporating Warm Asphalt Additive," Int. Res. J. Eng. Technol., vol. 4, no. 2, pp. 1239$1244,2017$.

[16] J. Ochepo, A. B. Salahudeen, and J. A. Sadeeq, “Assessment Of Bagasse Ash Effect On The California Bearing Ratio Of Used Oil Contaminated Lateritic Soils," vol. 34, no. 2, pp. 223-231, 2015.

[17] Patrick, Khaoya Barasa; Too, Kiptanui Jonah; Mulei, "Stabilization of Expansive Clay Using Lime and Sugarcane," Math. Theory Model., vol. 5, no. 4, pp. 124-135, 2015.

[18] K. J. Osinubi, V. Bafyau, and A. O. Eberemu, "Bagasse ash stabilization of lateritic soil," Appropr. Technol. Environ. Prot. Dev. World Sel. Pap. from ERTEP 2007, July 17-19 2007, Ghana, Africa, pp. 271-280, 2009.

[19] BS 1377. "Methods of testing soils for civil engineering purposes". British Standard Institute, London, Great Britain, 1990.

[20] BS 1924. "Methods of tests for stabilized soils." British Standard Institute, London, Great Britain, 1990.

[21] ASTM C618-93 specification "Fly Ash and Raw or Calcined Natural Pozzolan for use as Mineral Admixture in Portland Cement Concrete". Philadelphia, American Society for Testing and Materials, 4(2), 1992.

[22] NBRRI (Nigerian Building and Road Research Institute), Engineering properties of black cotton soils of Nigeria and related pavement design, NBRRI research paper no. 1, p 22, 1983.

[23] A. U. Chinade, S. Y. Umar, and K. J. Osinubi, "Effect of municipal solid waste leachate on the strength of compacted tropical soil for landfill liner". International Research Journal of Engineering and Technology, 4(6), 3248-3253, 2017.

\section{Biography}

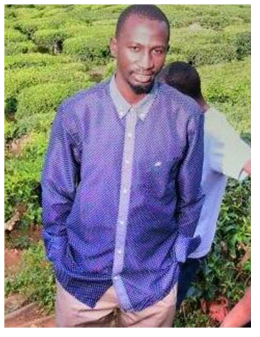

Ahmad Batari, received his B. Eng. (Civil) in 2011 from Abubakar Tafawa Balewa University (ATBU), Bauchi while his M. Eng. Civil Engineering was obtained from Universiti Tun Hussein Onn Malaysia (UTHM) in 2016. He is a lecturer with the Department of Civil Engineering ATBU, Bauchi, Nigeria, his research interest include; Pavement Materials, Transportation Planning, and Sustainable Transportation.

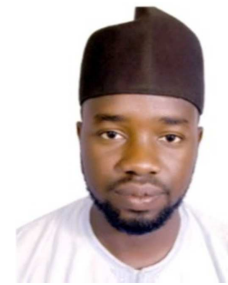

Adamu Umar Chinade, is an Assistant lecturer in the Department of Civil Engineering, Abubakar Tafawa Balewa University, Bauchi Nigeria. He had his B. Eng. (Civil) in 2011 and M. Eng. In Civil Engineering from ATBU, Bauchi. His research interests include Ground Improvement and Geoenvironmental Engineering.

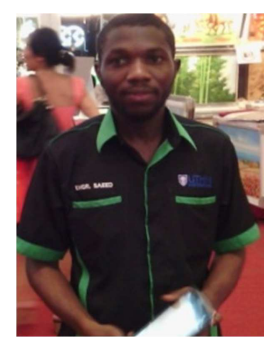

Saeed Modibbo Saeed, obtained his B. Eng. from ATBU, Bauchi in 2011; while he received his M. Eng. Civil Engineering from UTHM in 2016. He is also a lecturer with the Department of civil engineering ATBU, Bauchi, Nigeria, his areas of research include; Pavement Materials, Transportation Planning, and Sustainable Transportation.

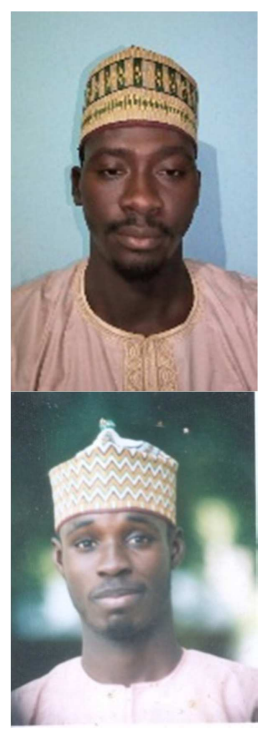

Ibrahim Abdulkarim Ikara, is currently an Assistant lecturer at the Civil Engineering Department, Abubakar Tafawa Balewa University, Bauchi Nigeria. He had his M. Eng. In Civil Engineering (Geotechnical) in 2016.

Nasir Kabir, obtained his B. Eng (Civil) from Bayero University Kano, Nigeria and presently pursuing his M. Eng in Structural Engineering at Abubakar Tafawa Balewa University, Bauchi, Nigeria. $\mathrm{He}$ is an Assistant Lecturer in the Department of civil Engineering at Abubakar Tafawa Balewa University. His research interests include Supplementary Cementitious Materials, Composite Fiber and High Performance Concrete.

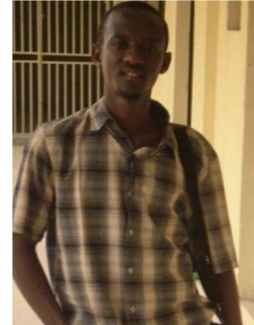

Reliability.
Abubakar Mamuda, had his B. Eng (Civil) from MAUTECH Yola, Nigeria and presently pursuing his M. Eng in Structural Engineering at ATBU, Bauchi, Nigeria. Also, an Assistant Lecturer with the Department of civil Engineering, ATBU, Bauchi. His research interests include Composite Structures and Structural 